\title{
CARING FOR FAMILY MEMBERS IN THE ICU: CHALLENGES FACED BY NURSES IN THE INTERPERSONAL PRAXIS OF USER EMBRACEMENT
}

\author{
Carolinny Nunes Oliveira1, Emanuelle Dias Caires Araújo Nunes²
}

\footnotetext{
${ }^{1}$ Nurse. Universidade Federal da Bahia (UFBA). Vitória da Conquista, Bahia, Brazil. Email: carolinnynunesoliveira@gmail.com

${ }^{2}$ M.Sc. in Nursing and Health. Assistant Professor at UFBA. Vitória da Conquista, Bahia, Brazil. Email: emanuelecdanunes@ gmail.com
}

\begin{abstract}
The objective of this study was to understand the interpersonal process of embracement between nurses and family members in an adult ICU. It is exploratory, descriptive and observational study, with a qualitative approach, conducted among ten nurses working in an adult ICU, selected using non-probabilistic sampling and established by data saturation, based on three data collection techniques: theme-drawing-text, semistructured interviews and non-participant observation. The analysis, based on Peplau's Theory of Interpersonal Relations and from a tridimensional focus, identified: reason, emotion and volition, that the embracement provided to families manifested certain shortcomings related to the communication process, the development of autonomy for discharge and the interpersonal relationship between nurses and the family. The nurses' concepts in relation to user embracement were positive, demonstrating their willingness to provide it, although they encounter formational and experiential difficulties in putting this nursing theory into practice, insofar as interpersonal relationships and, consequently, in the embracement of families.
\end{abstract}

DESCRIPTORS: Professional-family relations. Nursing. Intensive care. User embracement

\section{CUIDANDO DA FAMÍLIA NA UTI: DESAFIO DE ENFERMEIROS NA PRÁXIS INTERPESSOAL DO ACOLHIMENTO}

\begin{abstract}
RESUMO: Estudo que objetivou compreender o processo interpessoal de acolhimento entre enfermeiros e família em UTI adulto. Possui caráter exploratório, descritivo e observacional, com abordagem qualitativa, realizado com 10 enfermeiras atuantes em UTI adulto, selecionadas por amostragem não probabilística e delimitadas pela saturação dos dados, a partir de três técnicas de coleta de dados: tema-desenho-texto, entrevista semiestruturada e observação não participante. A análise identificou, à luz da Teoria do Relacionamento Interpessoal de Peplau, e sob o foco tridimensional: razão-emoção-volição, que o acolhimento à família apresenta lacunas referentes ao processo comunicacional, ao desenvolvimento da autonomia para alta e ao relacionamento interpessoal entre enfermeiro e família. As concepções atribuídas pelos enfermeiros ao acolhimento foram positivas, demonstrando intencionalidade em realizá-lo, embora encontrem dificuldades formadoras e experienciais referentes à prática desta teoria de enfermagem, ao relacionamento interpessoal e, consequentemente, ao acolhimento à família.
\end{abstract}

DESCRITORES: Relações profissional-família. Enfermagem. Terapia intensiva. Acolhimento.

\section{CUIDANDO DE LA FAMILIA EN LA UTI: RETO DE ENFERMEROS EN PRAXIS INTERPERSONAL DEL ACOGIMIENTO}

RESUMEN: Estudio tuvo como objetivo comprender el proceso interpersonal de acogimiento entre enfermeros y la familia en unidades de cuidados intensivos de adultos. Tiene un enfoque exploratorio, descriptivo, observacional cualitativo, realizado con 10 enfermeros que trabajan (muestreo no probabilístico y limitada por la saturación de los datos) de tres técnicas de recolección de datos: temadibujo-texto, entrevistas semi-estructuradas y observación no participante. El análisis identificó, a la luz de la Teoría de las Relaciones Interpersonales de Peplau y en el marco del enfoque tridimensional: razón-emoción-volición que el acogimiento a la familia tiene lagunas con respecto al proceso de la comunicación, el desarrollo para la autonomía del descargas y las relaciones interpersonales entre enfermero y familia. Sin embargo, los conceptos asignados por enfermeros al acogimiento fueron positivos, lo que demuestra que ellos tienen la intención de llevar a cabo, aunque encuentren dificultades formadoras y experienciales en lo que respecta a la práctica de esta teoría de enfermería, las relaciones interpersonales y en consecuencia el acogimiento a la familia.

DESCRIPTORES: Relaciones profesional-familia. Enfermería. Cuidados intensivos. Acogimiento. 


\section{INTRODUCTION}

This study was developed in response to concerns arising in the Intensive Care Unit (ICU) that the care given by nurses was losing its humanized essence in the face of widespread technology. Nursing, since its historical and cultural inception, emerged as a profession centering on individual human care relations. This is the existential foundation of nursing, representing its primary fully autonomous activity. ${ }^{1}$ However, providing humanized care in ICUs is made more difficult by the complexity of these units, which distances nurses from the human values underlying the profession.

In this respect, some strategies have been formulated, encouraging changes in caring for users, such as the National Hospital Humanization Program (PNHAH, as per its acronym in Portuguese) and the Collegiate Board Resolution n. 7, of 2010. This program proposes the implementation of interventions aimed at humanizing and improving the link among health workers, patients and family members. ${ }^{2}$ The resolution reaffirms the importance of the subjective and social dimension of care practices and ICU management, strengthening the commitment toward the rights of citizens. ${ }^{3}$

Nowadays, it is a major challenge to combine humanistic values in ICU care with the high technology required in such units. This challenge, in terms of ethical practice, is defined in this study as the act of embracing, and doing so provides a means for professionals who desire to restore humanized health care. Within this context, there is also the family and its need for care and embracement, based on interpersonal relations, since it is also drawn into the illness process due to its deep connection with the critically ill patient, which generates emotional upheaval and uncertainty as to the future. ${ }^{4}$

Peplau's Theory of Interpersonal Relations, which involves four relational phases, orientation, identification, exploitation and resolution, is a useful tool for understanding the importance of the relationships between nurses and the patient-family. In the orientation phase, the nurse introduces herself and orients the patient, while endeavoring to understand the person's health problem. In the identification phase, the patient develops the ability to deal with his or her problem in a positive way. In the exploitation phase, the patient deepens the interpersonal relationship with the nurse to obtain health benefits and fully use the services that are being offered. In the resolution phase, which does not always coincide with the patient's complete recovery, there is gradually less identification with the nurse and greater autonomy as far as taking care of one's own health. ${ }^{5}$

This theory was used in this study due to its importance as a scientific tool for understanding care relations in nursing. Although not originally intended to encompass family members, the theory also contributes to their care, since they are involved in the patient's illness and become subjects in the care process.

In addition to the aforementioned, this study is also relevant due to the shortcomings found in the literature review performed, where most of the studies confirm that providing embracement to family members is still a challenge in ICUs. This study, therefore, aims to overcome this challenge, primarily through the proposed adaptation of the Theory of Interpersonal Relations to the embracement of family members.

Thus, the study is guided by the following question: how is the interpersonal process of embracement between nurses and family members in the ICU developed? And its overall objective is: understand the interpersonal process of embracement between nurses and family members in the ICU; and more specifically, discover the meaning that nurses attribute to this embracement, as well as analyze the relational process between nurses and family members from the perspective of $\mathrm{Pe}$ plau's theory.

\section{METHODOLOGY}

This is an exploratory, descriptive, observational and qualitative study, conducted in two adult ICUs in a general hospital in the state of Bahia, which, together, have 15 beds of regional reference and provide diversified care, primarily in relation to traumas. The study involved the participation of ten nurses, selected via a non-probabilistic sample by convenience, and established by data saturation, with the inclusion criterion of having worked for at least six months in the ICU.

Data collection took place from June to August 2013 and involved a variety of techniques performed chronologically in the following order: non-participant observation, the drawing-themetext technique and, lastly, semistructured interviews. It was decided to use this order to minimize the interference of the instruments in the stance/ discourse of the subjects. The non-participant ob- 
servation followed a printed script in the form of a checklist, followed by notes made in a field journal regarding the observation. The script contained the following questions: Does the nurse introduce him/herself to the family? Does the nurse provide information about the pathology, the patient's general state and the rules and routines of the ICU? Does the nurse make him/herself available to provide help and any explanations? Does the nurse encourage family members to talk with the patient? Does the nurse seek psychology, social assistance or other services, if needed? Does the family see the nurse as a source of support? Is the interpersonal relationship between the nurse and family harmonious and beneficial for both sides? Is the family dependent on the nurse? Does the nurse instruct the family on future care of the patient once discharged from the ICU? Does the family feel motivated and confident to care for the patient without the nurse? The purpose of this script is to discover whether an interpersonal relationship exists between nurses and family members, covering the phases of Peplau's Theory, according to the adaptation proposed for this study.

Observation was the first avenue for collecting data so that behavior could be detected before directly addressing the theme using the other instruments. It took place on random days and schedules so as not to draw the attention of the subjects, who did not know they were being observed. These sessions were divided into fourhour periods, totaling 48 hours of observation, which included time on all three work shifts (morning, afternoon and night), and included repetitive observation of situations more conducive to understanding the relationship between family members and nurses, such as during admission, discharge, visits and death.

The theme-drawing-text technique was used to collect data individually and occurred in the staff meeting room, in the ICU, providing the subjects with privacy. Each participant was given sheets of A4 paper, color pencils, chalk and lead pencils, and was requested to freely draw a picture. "What is embracement?" After the drawing was completed, the participant was invited to explain the drawing verbally, giving it a title (recorded comments that were afterwards transcribed in order to integrate the results and obtain the meaning of the images that were not analyzed psychologically). Following this, in the same location, a semistructured interview took place, guided by the questions: "How do you view the families of your patients who are in the ICU?"; "How is an interpersonal relationship established between you, the nurse, and the family?"; "What is difficult for you in the process of embracement for these family members? And what is easy?"; "Are you satisfied with the embracement you provide? Why or why not?" The interviews were recorded and transcribed a posteriori.

The data obtained were manually organized and analyzed through an interactive analysis model. They were initially broken down into pillars according to the objectives. Data were then presented as an organized and compact set of information and, lastly, examined/ interpreted to uncover their meanings. ${ }^{6}$

This study adhered to the ethical principles established in resolution no. 466/2012 and was approved as per protocol n. 297.139/ 2013 of the Human Research Ethics Committee of the Federal University of Bahia, Multidisciplinary Health Institute. The subjects signed a Free and Informed Consent Form and were assigned code names of precious and semi-precious stones to protect their anonymity.

\section{RESULTS AND DISCUSSION}

The data obtained were grouped into four pillars, corresponding to the phases of Peplau's Theory of Interpersonal Relations: orientation, identification, exploitation and resolution. In addition, each pillar contained three sub-classifications that were enhanced through the three data collection techniques used: emotion, which is linked to feelings and subjectivity, and corresponds to the data from the drawings, representing the subjective feelings of the nurses; reason, which involves rational and intellectual thoughts, as expressed through the responses given in the interview; and volition, representing intention and action, which is compared with the observation data where the intentions and practice of the nurses, insofar as user embracement were examined.

The order of presentation of the results of the multiple techniques differs from the order of collection since, for the nurse, the subject of the study, the data collection began with the expression of their subjective feelings (drawing), followed by rationality (interview), elements which are analytically compared with the actions already observed in the ICU, without the subject being aware that it was taking place. 


\section{Pillar I - Orientation: the first steps of the} process

Orientation, a moment permeated with deep psycho-emotional suffering, which represents the first contact of the family with the ICU environment and also with the nurse. During this time the nurse is supposed to orient the family about the state of the patient and the rules and routines of the ICU, primarily information regarding visiting hours.

\section{Emotion: subjective feelings about the first meeting underlying the drawings in the orientation phase}

From the data obtained through the themedrawing-text technique, following are some descriptions related to the orientation and reception of the family in the ICU, which reveal the subjectivity of the embracement given by the nurse to the family, during their first contact with the ICU.

I represented user embracement as receiving the family well, and for this reason the heart at the door [...] [Drawing: Care] (Diamond).

In my drawing [...] user embracement represents the importance of listening and being prepared and sensitive to recognize the needs of family members [Drawing: Communication] (Sapphire).

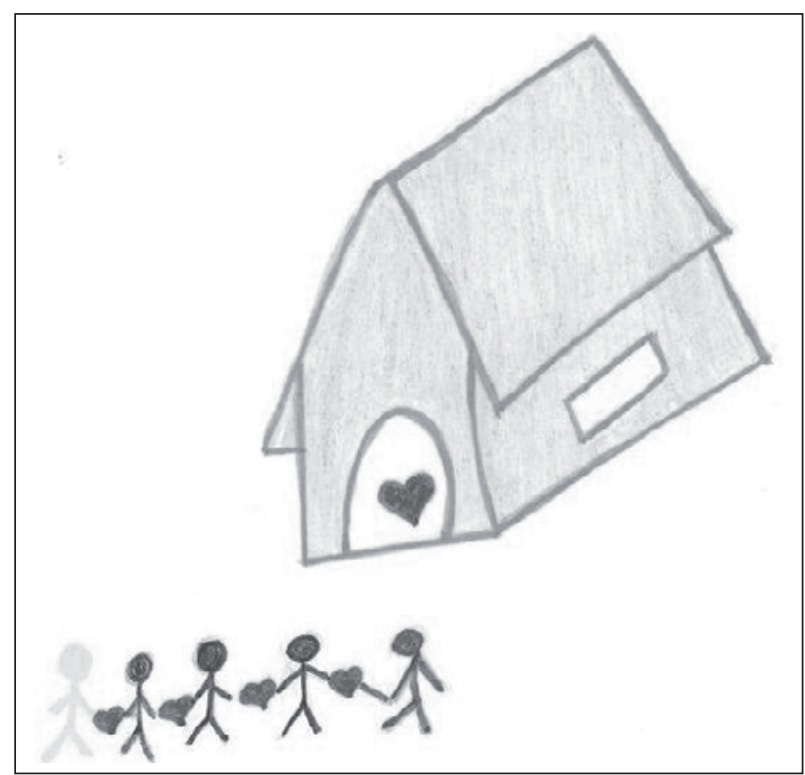

Figure 1 - Care

It was noted, from the subjective perspective of the nurses, that embracement to the family is linked to two central ideas: receiving them well and the importance of listening, in order to meet the family's care needs. However, user embracement is more than interested listening and should not be limited to welcoming people at the door of the health services, but implies an ongoing process comprised of listening, identification of problems and resolution-based interventions occurring throughout the entire flow of care. ${ }^{7}$ Therefore, the ideas nurses have about user embracement should also include the idea of continuity, since receiving the family well, listening to them and meeting their needs are actions that should take place in every encounter with family members in the ICU.

\section{Reason: the rational side of embracement in the orientation phase}

In the semistructured interviews, the nurses highlighted admission as the main opportunity for providing families with information in the orientation phase.

[...] during admission, I talk with the family [...], tell them about visiting hours, what personal and hygiene items the family member needs to bring for the patient [...] (Jade).

[...] during admission, I explain about visiting hours and what hygiene items need to be brought. I try to alleviate the family member's anxiety and comply with their requests as much as possible [...] (Diamond).

Another moment identified for providing the family with information was visiting hours. However, it is evident in the excerpts below that the nurses supply information to the family when there is an opportunity or when requested, and not as part of the job routine.

During visits, when I'm providing care of some kind, I take advantage to instruct the family [...], but unfortunately it's not something continuous that always happens [...] (Amethyst).

[...] when I notice that the family wants to talk, then I'm always there [...] waiting for that sign, waiting to be called upon [...] (Crystal).

These testimonies show that supplying information to the family during admission occurs naturally, due to the existence of a systematized admission procedure, but it is not exactly defined as the first step in interpersonal relations. The supply of information during visiting hours rarely occurs, only when there is an opportunity or when requested by the family. A socio-poetic study ${ }^{8}$ on what family members imagine will happen in the ICU found that they imagined that after being embraced and obtaining information they would be able to better define their feelings, and then 
focus their goals and motivation on waiting for the patient's expected recovery.

Thus, it can be noted that the continuous supply of information to the family is an element that creates a link and is essential in the family embracement process in the ICU setting.

\section{Volition: the intention to receive families well in the orientation phase}

During the observation focusing on the orientation phase, it was noted that admission was basically the main time that nurses supplied information to family members, since it is part of the work routine. Afterwards, nurses only supply information upon request, generally when they are at the patient's bedside during visiting hours in order to perform a certain procedure or administer medication. Apart from these situations, nurses take advantage of visiting hours to engage in other activities away from the family.

Therefore, there is a certain lack in the nursefamily interaction as far as information. Creating a closer contact between both parties during visiting hours is necessary, since the literature indicates that family members want to receive information from the nurse and consider that closer contact with this professional will satisfy their main needs for embracement, so that their doubts and anxieties can be alleviated. ${ }^{9}$ So, it can be concluded that providing information to the family is essential for proceeding to the next phase of the Theory of Interpersonal Relations, where once having received the help provided by the nurse, the family is able to deal positively with the situation.

\section{Pillar II - Identification: revealing emotions}

Identification represents the time when the family is more informed about the new situation in which it finds itself and identifies with the nurse, and is consequently developing the ability to deal more positively with the health problem of their loved one. At this juncture, there is a certain liberation and motivation on the part of the family to rise above its situation, and the initial negative emotions of anguish, despair and helplessness diminish.

\section{Emotion: revealing the emotions underlying the drawings in the identification phase}

The descriptions of the drawings related to the identification phase show how the nurses' con- cept of embracement is one of providing emotional support to family members.

[...] I drew [...] that user embracement is related to giving people a word of comfort, peace during such a difficult time [...] [Drawing: Support] (Jade).

In my drawing, I put [...] that to provide embracement the nurse must show compassion, empathy and support for the family [Drawing: Empathy] (Tourmaline).

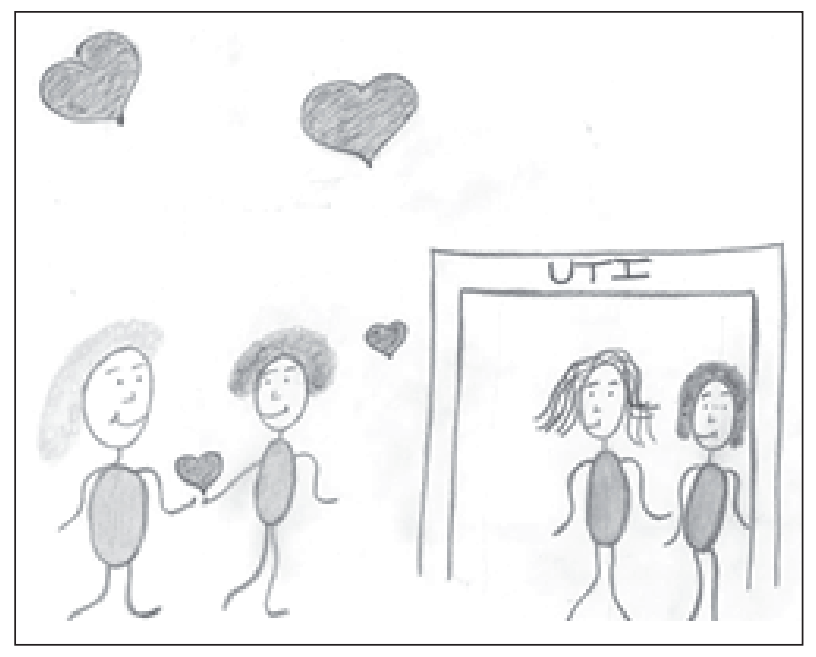

Figure 2 - Support

These comments indicate that the nurses recognize the transcendent nature of embracing the family in the ICU by its attribution of positive feelings to the latter. Another study also found that the nursing team associates family embracement with the following care characteristics: closeness, empathy, reception, communication, dedication and availability, and they assign importance to family embracement as a relevant care strategy in the ICU setting. ${ }^{10}$

The dilemma nurses encounter in practice is also revealed here, where professionals express subjective feelings about care and recognize the importance of humanization, but, due to a series of personal, professional and institutional factors they do not provide it, often because they are subjected to a mechanistic work regime, without appreciation and incentive, enveloped in an oppressive and stressful system, where there is no psychological support. This magnifies the challenges involved in providing embracement to families, since to care for others it is necessary to take care of oneself, because care occurs through a transmission of feelings. ${ }^{11}$

In this respect, there is a clearly need for openness regarding the subjective feelings of fam- 
ily members, as well as for nurses, who desire to embrace, but find themselves experiencing psychological distress due to the physical, psychological and social wear and tear inherent to working in an ICU, not to mention the lack of appreciation by the health team, shortage of material and human resources and insufficient financial incentives. ${ }^{12}$

\section{Reason: the emotions underlying rationality in the identification phase}

In the semistructured interviews, the nurses recognize the difficult time the family is going through and the importance of providing emotional support.

[...] I always try to transmit to the family the idea that the situation is complicated, but to be calm, trust that everything will turn out all right and to be strong and prepared [...] (Jade).

[...] when I notice a family member is sadder, hopeless, I try to give some words of comfort [...] (Ruby).

These results differ from other studies that found that nurses did not view the psychological distress of the family as an object of their care giving. ${ }^{13-14}$

However, we consider that there is an aspect in all human beings that predisposes them to include care in everything they do - care understood here as a responsibility related to being in the world and collaborating with the welfare of all; contributing to the maintenance of life. ${ }^{1}$ Therefore, despite all the adverse conditions cited above, there is still an inherent desire on the part of nurses to give care and intervene whenever a need is detected.

\section{Volition: the intention to embrace emotions during the identification phase}

During the observation focusing on the provision of emotional support by nurses, it was noted that, although they appear to maintain a distant attitude due to other activities they are performing during visiting hours, when they do detect an emotional need in family members, they feel empathy and, as much as possible, try to help, which unfortunately does not occur routinely, since it was seen that an interpersonal relationship had not been established between the nurse and family and, for this reason, it was observed that many family members did not feel comfortable exposing their feelings.
We believe that the failure to establish an interpersonal relationship between nurse and family is due to a combination of factors, related to both parties. In the case of the nurse, this includes factors such as lack of time to assist the family; fear of emotional involvement; impersonal behavior toward the family; and the family's perception of the nurse as an intruder. In terms of the family, there are factors such as tension, insecurity and fear regarding the situation; and lack of trust in the health team. ${ }^{15}$

However, the need for joint efforts is important, involving the institution, nursing staff and family, to overcome these barriers to establishing interpersonal relations, since the negative feelings experienced by the family during the time their loved one is hospitalized in the ICU are minimized by the embracement provided by the nurse, who prepares them for the time of the visit, listens to them, answers their questions and attends to their needs. ${ }^{16}$

\section{Pillar III - Exploitation: the intertwining of efforts}

Exploitation represents a time when the family deepens its interpersonal relationship with the nurse and starts benefiting from the latter, fully using the services it is being offered to help deal with the situation of their loved one in the ICU.

Emotion: the subjectivity of collaboration underlying the drawings in the exploitation phase

The drawing that is identified with the exploitation phase emphasizes embracement as collaboration between the nurse and family to help the patient recover.

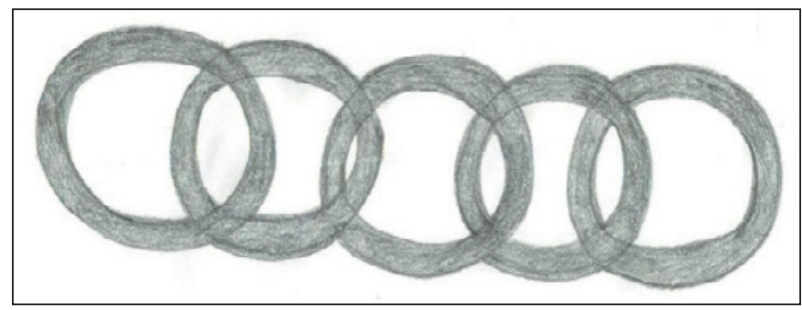

Figure 3 - Union

I drew a type of chain because, for me, embracement means involvement, being intertwined. When you embrace the family you are inviting them to join forces for the sake of the patient [Drawing: Union] (Pearl). 
User embracement was associated with assigning value to relationships, cooperation and the nurse and family joining forces for the patient's recovery. This concept is positive, because, in short, the objectives of user embracement are: acknowledgment of the other as a genuine person; recognition that each one is insufficient on his own and is only complete in the presence of the other; situations are built by combining the knowledge of all the individuals present. ${ }^{17}$ Thus, it should be emphasized that interpersonal relations, imbued above all with respect, are indispensable to establish embracement to the family in the ICU setting.

\section{Reason: rationality in the uniting of forces during the exploitation phase}

The comments in the semistructured interviews related to the exploitation phase stress the importance that nurses assign to the family in the patient's recovery.

The family is essential for the patient's recovery. They are able to restore abilities in the patient that we aren't able to [...] (Amethyst).

The family is very important [...]. Lack of contact with the family has a negative effect on the patient's emotional state and consequently on their physical state [...] (Pearl).

The nurses stress the importance of family members and attribute breakthroughs in the patient's recovery to them, which is consistent with a study ${ }^{10}$ that claims that the presence of family members is an essential supplement to treatment and found that nurses recognize the importance of family members in the recovery of patients.

However, collaboration with the family, as seen in the comments below, is still a challenge for the ICU nurses in this study.

One problem is the desperation and anxiety of the family member; [...] these negative feelings end up making the relationship unpleasant and draining. [...] (Jade).

The fact that ICU nurses can't disclose certain information about patients gets in the way of building a closer relationship, because whenever there is contact, the family members come and ask me things, but I can't answer them [...] this hinders interaction [...] (Crystal).

To provide better embracement [...] I need more time [...], the tasks, the work routine tie us down a lot, [...] Talking with the family is rare [...] (Emerald).

These difficulties do not only occur in the ICU in this study, but have been reported in other studies. ${ }^{10-16}$ However, these should not be viewed as insurmountable barriers to nurses embracing family members, since the rebuilding of humanized care requires effort to overcome certain challenges, which can be grouped into three main motivations: embrace the other in his or her biopsychological entirety, using light techniques such as embracement and bonding; optimize interaction, through sensitive listening that is able to elicit some type of response; and enrich the panorama through an interdisciplinary and intersectoral approach. ${ }^{18}$

\section{Volition: the intention to contribute with embracement during the exploitation phase}

During the observation it was noted that there was no deepening of the interpersonal relationship between the nurse and the family. When this relationship occurs it is superficial, since there is little involvement of nurses with family members. One of the reasons for this is that the nurses use visiting hours as a time to get away - to rest, have a coffee and unwind. Visiting hours are a crucial time for the nurse-family relationship, since, in dedicating time to help the family understand the aspects of its current situation, the nurse turns the hospital experience into a time of useful and transformational learning. ${ }^{5}$

\section{Pillar IV - Resolution: independence from the bonds}

Resolution is the phenomenon of psychological severance which does not always coincide with the patient's complete recovery and requires a gradual weaning of the family from the identification, bond and dependence on the nurse, as well as developing the ability to positively intercede in the complete recovery of their loved one.

\section{Emotion: the subjective feelings underlying the drawings in the resolution phase}

The drawing related to the resolution phase demonstrates that embracement also takes place through resolution of the demands of family members.

[...] I drew a path without any obstacles, which would be the movement of the family members to the resolution of their problems and the recovery of their loved one. Drawing: Care (Amethyst).

This larger figure here represents the ICU team, ready to receive the person to be embraced and to resolve all their needs [...] [Drawing: Resolution] (Crystal). 


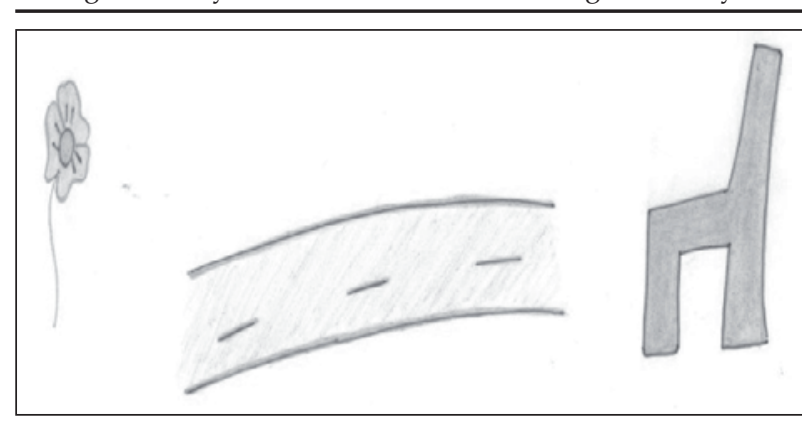

Figure 4 - Assistance

User embracement only materializes in the process of day-to-day health services through the link between the demand presented and the response of the health service, which translates into assuming responsibility for needs that are not immediately met, referring them in an ethical and solution-based way, through an interdisciplinary and inter-sectoral process, which occurs within a network of relationships involving interaction and constant dialogue. ${ }^{7,17}$ We noted that ICU nurses will not always be able to work out all the demands of family members, because it will often be necessary to summon the interdisciplinary team, but the nurse is responsible to tell the family what means it has at its disposal and ensure that it has access to those means.

\section{Reason: rationality toward the discharge in the resolution phase}

The semistructured interviews revealed that the nurses are aware of the need to prepare the family for discharge from the ICU, but scheduling this time rarely occurs. [...] Many patients are discharged from the ICU with a tracheostomy tube and family members need to be prepared to identify warning signals. I try to talk to them and explain, but I'm not always able to [...] this time to instruct the family on what to do to help with the patient's recovery outside the ICU doesn't exist [...] (Amethyst).

As we noted, no preparation is given for the discharge of patients from the ICU being studied here. It is also our understanding that this preparation should begin right after admission to the unit, since at the time of discharge, it will be difficult for family members to grasp all the necessary elements involved in the future care of the patient. For this reason, family members need to receive instruction on a daily, continuous basis, so that they will feel secure and qualified to administer care on their own. ${ }^{19} \mathrm{We}$ would also like to emphasize that if the nurse combines intuition, experience, interest, respect and sensitivity with the technical and scientific aspects of the care in his or her relationship with family members, it will make them feel secure and confident in the future. ${ }^{1}$

\section{Volition: the intention to properly finalize the embracement given}

During the observation the need was noted for scheduling a time to prepare family members for the discharge of the patient who often leaves the ICU with mechanisms such as ostomies and catheters. However, it was seen that this time of instruction does not generally occur, and the family feels insecure in relation to future care of the patient outside the ICU.

It is worth noting that successful future patient care depends on the family's participation and preparation during the period of hospitalization, providing it with the necessary information and reassurance so that they will feel confident and capable to continue caring for the patient on their own without the ICU team. ${ }^{19}$ The moral ideal of nursing consists of behaviors and attitudes that empower the family to maintain or improve its situation, helping family members to grow, change and find meaning in the most difficult of times, in order to achieve a state of restored internal harmony. ${ }^{1}$

\section{FINAL CONSIDERATIONS}

In seeking to understand the interpersonal process of embracement between nurses and family members in the ICU, it can be concluded that these objectives were achieved, although none of the participants had considered all the phases of Peplau's Theory of Interpersonal Relations, in any of the three data collection methods used.

This demonstrates that shortcomings exist in the training of nurses regarding interpersonal relations and, consequently, in the embracement provided to family members. In addition, it is clear that sub-importance is given to nursing theories that in the past represented major scientific advances for the profession, but which, unfortunately, are gradually falling into oblivion. This is a cause for concern, since the theory makes it possible to analyze the relational process and identify important shortcomings in the interpersonal relations between nurses and families in the ICU setting, thus demonstrating its relevance in this context. 
The analysis and systematization of the interpersonal relationship between the nurse and family, based on Peplau's Theory of Interpersonal Relations, found that the embracement provided to families in the ICU under study had major shortcomings, such as lack of providing information to the families during visiting hours, failure to establish personal relations between the nurse and family and lack of a scheduled time to prepare for the patient's discharge. However, with effort and systematization of the interpersonal relationship through employing the premises of the theory and embracement, these shortcomings can be overcome.

The concepts of nurses toward family embracement were positive, demonstrating that they are willing and have the potential to provide it. Placing family embracement in the list of nursing duties is a reality in other ICUs, with satisfactory results, indicating that it is possible, in this setting, to combine highly technological care with attentive and informational dialogue.

Therefore, we suggest that the embracement of family members be implemented in the ICU, based on the premises of the Theory of Interpersonal Relations, so that this practice will no longer be so scant, piecemeal and insufficient, but will become cyclical and continuous, in relation to providing families with the necessary assistance so that they will feel truly cared for. We also suggest ongoing educational and psychological support activities, in terms of preparing nurses to provide this embracement, since when interpersonal relations are intensified, the emotional impact on those involved is also greater, demonstrating the need for support to deal with this emotional overload.

Finally, we would like to stress the commitment of ICU nurses toward family members, who are active subjects in the care process and extensions of the critically ill patient, making it necessary to rethink current practices and explore sensitive and innovative means that can help with the transformation needed in this setting.

\section{REFERENCES}

1. Waldow VR. Cuidar: expressão humanizadora da enfermagem. 3a ed. Petropólis (RJ): Vozes; 2010.

2. Ministério da Saúde (BR). Portaria n. 881 de 19 Jun. 2001: Institui no âmbito do SUS, o Programa Nacional de Humanização da Assistência Hospitalar. Brasília (DF): 2001.

3. Ministério da Saúde (BR). ANVISA. Resolução da Diretoria Colegiada de n. 7, de 24 de fev 2010. Dispõe sobre os requisitos mínimos para funcionamento de UTI e dá outras providências. Diário Oficial da União, Brasília, 25 de fev. de 2010. Seção 1: 48-52.

4. Ismael SMC. A família do paciente em UTI. In: Melo Filho J, Burd M. Doença e família. $2^{\mathrm{a}}$ ed. São Paulo (SP): Casa do Psicólogo; 2010. p.253-7.

5. Peplau HE. Relaciones interpersonales en enfermería: um marco de referência conceptual para la enfermería psicodinámica. Barcelona (ES): Masson-Salvat; 1990.

6. Miles MB, Huberman AM. Qualitative data analysis: an expanded sourcebook. $2^{\mathrm{a}}$ ed. California (US): Sage, 1994.

7. Solla JJSP. Acolhimento no sistema municipal de saúde. Rev Bras Saúde Matern Infant. 2005 Out-Dez; 5(4):493-503.

8. Silva FS, Santos I. Expectativas de familiares de clientes em UTI sobre o atendimento em saúde: estudo sociopoético. Esc Anna Nery Rev Enferm. 2010 Abr-Jun;14(2):230-5.

9. Simoni RCM, Silva MJP. O impacto da visita de enfermagem sobre as necessidades dos familiares de pacientes de UTI. Rev Esc Enferm USP. 2012; 46(Esp):65-70.

10. Martins JJ, Nascimento ERP, Geremias CK, Schneider DG, Schweitzer G, Mattioli Neto H. O acolhimento à família na unidade de terapia intensiva: conhecimento de uma equipe multiprofissional. Rev Eletr Enferm [online]. 2008 [acesso 2013 Jan 9]; 10(4). Disponível em:http://www.fen.ufg.br/ fen_revista/v10/n4/v10n4a22.htm

11. Silva GF, Sanches PG, Carvalho MDB. Refletindo sobre o cuidado de enfermagem em unidade de terapia intensiva. REME Rev Min Enferm. 2007 Jan-Mar; 11(1):94-8.

12. Shimizu HE, Couto DT, Merchan-Hamann E. Prazer e sofrimento em trabalhadores de enfermagem de UTI. Rev Latino-Am Enferm [online]. 2011 [acesso 2013 Jan 8]; 19(3). Disponível em: http:/ / www. scielo.br/pdf/rlae/v19n3/pt_16.pdf

13. Bettinelli LA, Erdmann AL. Internação em unidade de terapia intensiva e a família: perspectiva de cuidado. Avances Enfermería [online]. 2009 [acesso 2013 Jan 9]; 27(1). Disponível em: http://www. enfermeria.unal.edu.co/revista/articulos/xxvii1_2. pdf

14. Predebon GR, Beuter M, Flores RG, GirardonPerlini NMO, Brondani CM, Santos NO. A visita de familiares em unidades intensivas na ótica da equipe de enfermagem. Cienc Cuid Saude. 2011; 10(4):705-12.

15. Ruedell LM, Beck CLC, Silva RM, Lisboa RL, Prochnow A, Prestes FC. Relações interpessoais entre profissionais de enfermagem e familiares em UTI: estudo bibliográfico. Cogitare Enferm. 2010 Jan-Mar; 15(1):147-52. 
16. Frizon G, Nascimento ERP, Bertoncello KCG, Martins JJ. Familiares na sala de espera de uma UTI: sentimentos revelados. Rev Gaúcha Enferm [online]. 2011 [acesso 2013 Jan 7]; 32(1). Disponível em: http://www.scielo.br/pdf/rgenf/v32n1/ a09v32n1.pdf

17. Teixeira RR. O acolhimento num serviço de saúde entendido como uma rede de conversação. In: Pinheiro R, Mattos RA (organizadores). Construção da integralidade: cotidiano, saberes e práticas de saúde. $4^{\text {a }}$ ed. Rio de Janeiro (RJ): UERJ, IMS: Abrasco, 2007. p. 91-113.
18. Ayres JRCM. Cuidado e reconstrução das práticas de saúde. Interface - Comunic Saúde Educ [online]. 2004 [acesso 2013 Jan 8]; 8(14). Disponível em: http://www.scielo.br/pdf/icse /v8n14/v8n14a04. pdf. 19 de jan. de 2013.

19. Silva RB, Oliveira BRG, Collet N, Viera CS. O papel da equipe de enfermagem nas orientações à família sobre os cuidados no domicílio ao RN egresso de UTI neonatal: pesquisa bibliográfica. Online Brazilian J Nursing [online]. 2006 [acesso 2013 Jan 9]; 5(3). Disponível em: http:/ / www.objnursing.uff.br/ index.php/nursing/article/view/738/168 